\title{
Ei enää autoritaarista opettamisen mallia!
}

Ei ole tärkeää mitä ja miten sanoo, tärkeäm. pää on se reaktio, minkä synnyttää.

Tämä ajatus ihmisen kasvusta tuli mieleen, kun kuunteli radiosta syyskuun lopussa aikuiskasvatusteoreetikon esitelmää aikuisdidaktîkasta. Oppimisprosessin aikaansaaminen on havaitsemaan ja ajattelemaan saamista. En voi ymmärtää, miten tästä prosessista voi yleensäakään tehdä teoriaa kaventamatta ihmiskäsitystä ja ajatteluprosessia.

"Lasten ja aikuisten opettaminen on täysin erilainen tapahtuma", sanoo teoreetikko. Niinkö? Yhä useammin törmään tilanteeseen, jossa lapset ja nuoret opettavat aikuisia tai aim nakin opetettavassa ryhmässä on eri ikäisio ih. misiä?

En saa aikuisopetusteorectikon ajatusmallia millään sopimaan pitkään kokemukseeni eni ikäisten ihmisten parissa tapahtuneisin oppl. miskokemuksiini opettajana. Puhuuko hän tiedottamisesta? Ei, kyllä hän puhuu opettamisesta. Suis oppimisprosessista? Ei, puhe ei sisällä oppimisprosessia vuorovaikutustapahtumana. Voidaanko puhua opettamisesta ilman sitä!

"Lasten opettaminen on erilaista kuin aikuisten opettaminen", hän sanoo. Hän puhuu kuin lapselle. Tiedän että, jos hän puhuisi lapsille, hän puhuisi heille kuin aikuisille. Hänen persoonassaan tarttumapinta on ohut. Lapset ja muut luovat olennot eivät siihen saa tartumaa. Teoria toimii keskivertopopulassa.

Opettamisen prosessin syvällinen ymmärtäminen edellyttäa vuorovaikutustapahtuman syvällistä kokemista. Teoriaa näistä asioista saisi tehdä vasta pitkäaikaisen ja perusteellisen oman persoonan testam taus pitäisi tapahtua eri ikäisten ja erilaisia kokemuksia omaavien ihmisten kanssa. Vuoro vaikutustaito olisi hiouduttaya, kunnes toisten kuunteleminen syvenisi ryhmäpr $\bullet$ sessin intui. tiviseksi tajuamiseksi.

Tässä vaiheessa tiedottaminen muuttuu opettamiseksi, ja vähitellen oppimisprosessiin osallistumiseksi. Opettaja on kulkenut ulos au- toritaarisesta opettamisen mallista, joka on tiedottamista ja tiedon vastaanottamisen arvi-. oimista omasta näkökulmasta käsin. Tällä opettamisella ei nyky-yhteiskunnassa ole juuri merkitystä. Tielotamisen hoitavat viestintävälineet, opettajan tchtävä sen sijaan on jotain muuta. Se on ymmärtämisen prosessin alkuun saamista ja edellyttää, että opettajan persoonassa on tarttumapintaa ihmisessä olevalle Ai kuiselle, Lapselle ja Vanhemmalle. Tiedottamisessa Vanhempi puhuu Lapsille - on kyseessä työ, jota aikuiskasvatusteoreetikko juuri nyt minun radiossani minulle tekee.

Autoritaarisesta Vanhemman puheesta Lap sille voi pitää kiinni täsmälleen niin kauan, kunnes uskaltautuu itse koko persoonallaan vuorovaikutusprosessiin, todella kuuntelemaan toisia koko olemuksellaan. Kyse on siis eräästä ibmisen kehityksen kynnyksesta. Kyse on myös yhteiskunnan toimintamallien muut. tumisen havaitsemisesta.

Oman persoonan testaus on tärkeämpää kuin teoriatiedon omaksuminen oppimistapahtumasta. Vasta eri ikäisten pitkäaikainen kasvuprosessista vastullinen toiminta auttaa näkemään vuorovaikutusprosessin monitasoisuden oppimistapahtumassa. Havaitsemisen ja ajattelun herättäminen ovat olennaisia niin lasten kuin aikuisten oppimisessa.

Mitä on opittu, mitä on ymmärretty, sen voi nähdä ihmisen elämänasenteissa ja toiminnassa yhteiskunnassa. Kun koko oppimisprosessia tarkastelee, on pakko havaita, että aikuisia on opetettava siten, että niin Lapsi, Aikuinen kuin Vanhempikin saavat vuorovaikutuskosketuksen. Täsmälleen niin kuin lastenkin opetuksessa. Erot eri ikäisten opettamisessa ovat toisarvoisia. Kaventuneeseen oppimis- ja opettamisteoriaan päädytään vain jos unohdetaan tarkastella oppimisen merkitystä yleensä yhteiskunnassa.

Minkälaisia ovat oppineet yhteiskunnassa? Mikä merkitys oppineisuudella heille on? Onko se kasvamista ihmisenä vai jotain muta. 